\title{
Effects of spent mushroom substrate and slurry on nutritional value of grass and Medicago $x$ varia $T$. Martyn mixtures
}

\author{
Kazimierz Jankowski, Elżbieta Malinowska, Jacek Sosnowski, Beata Wiśniewska-Kadżajan, \\ Anna Kaczorek
}

(Siedlce University of Natural Sciences and Humanities, Department of Grassland and Landscape Architecture Development, Institute of Agronomy, Poland)

\begin{abstract}
The paper aimed to evaluate fertilizing effects of spent mushroom substrate (SMS) and slurry on dry matter productivity and value of legume-grass mixtures. The experiment was replicated three times, with a split-plot arrangement and plots of $3 \mathrm{~m}^{3}$ as experimental units. These species were grown as three legume-grass mixtures: $\mathrm{M}_{1}-$ Dactylis glomerata, Lolium perenne, Medicago x varia T. Martyn; $\mathrm{M}_{2}-$ Dactylis glomerata, Medicago x varia T. Martyn; $\mathrm{M}_{3}-$ Lolium perenne, Medicago x varia T. Martyn. The experiment consisted of the following units: control (no fertilization); SMS (30 t/hm²); slurry $\left(60 \mathrm{~m}^{3} / \mathrm{hm}^{2}\right)(\mathrm{G})$; SMS $\left(10 \mathrm{t} / \mathrm{hm}^{2}\right)+$ slurry $\left(60 \mathrm{~m}^{3} / \mathrm{hm}^{2}\right)$; SMS $\left(20 \mathrm{t} / \mathrm{hm}^{2}\right)+$ slurry $\left(40 \mathrm{~m}^{3} / \mathrm{hm}^{2}\right)$; SMS mushroom substrate $\left(30 \mathrm{t} / \mathrm{hm}^{2}\right)+$ slurry $\left(20 \mathrm{~m}^{3} / \mathrm{hm}^{2}\right)$. During each growing season all the mixtures were harvested three times. The fresh matter from each plot was weighted and a sample of $0.6 \mathrm{~kg}$ was taken for further analysis. In the experiment the content of both total protein and crude fibre was dependent on the type of fertilizer and on the type of mixture. Forage from the plots with $20 \mathrm{t} / \mathrm{hm}^{2}$ of mushroom substrate and $40 \mathrm{~m}^{3} / \mathrm{hm}^{2}$ of slurry had the best nutritional value, with the highest amount of total protein. The contents of protein and crude fibre in the forage were more favourably affected by slurry than by spent mushroom substrate. Out of the mixtures from all plots, regardless of the type of fertilizer, the mixture consisting of Lolium perenne and Medicago $x$ varia $\mathrm{T}$. Martyn contained the highest content of protein.
\end{abstract}

Keywords: fertilizer, spent mushroom substrate, nutritional value, protein concentration, fibre concentration DOI: $10.25165 /$ j.ijabe.20181103.3726

Citation: Kazimierz J, Elżbieta M, Jacek S, Beata W, Anna K. Effects of spent mushroom substrate and slurry on nutritional value of grass and Medicago x varia T. Martyn mixtures. Int J Agric \& Biol Eng, 2018; 11(3): 61-66.

\section{Introduction}

In crop rotation, growing grass after other crops repeatedly on the same field affects crop yields and soil quality in a positive way. In this type of farming the quality of the yield is also an important issue, while cultivation of legume-grass mixtures brings well-balanced fodder. According to Gawe ${ }^{[1]}$ these mixture plays a large role in both integrated and organic production systems. Thus, legume-grass mixture is a source of very valuable fodder of balanced chemical composition, with components that absolutely necessary in animal nutrition ${ }^{[2-5]}$. In addition, crops are one of the cheapest fodder sources, and have beneficial effects on follow-up crops, leaving the soil in good condition ${ }^{[4,5]}$.

In organic farming, it is important to use organic fertilizer that safe for the environment. In the meantime, it should favourably affect the yield and quality of crops. Slurry and spent mushroom

Received date: 2017-08-18 Accepted date: 2018-03-08

Biographies: Kazimierz Jankowski, Professor, research interests: plant production, grassland science, Email: kazimierz.jankowski@uph.edu.pl; Elżbieta Malinowska, $\mathrm{PhD}$, Associate Professor, research interests: plant production, grassland science, Email: elzbieta.malinowska@uph.edu.pl; Beata Wiśniewska-Kadżajan, $\mathrm{PhD}$, Associate Professor, research interests: plant production, grassland science, Email: beata.wisniewska-kadzajan@uph.edu.pl; Anna Kaczorek, PhD, research interests: plant production, grassland science, Email: laki@uph.edu.pl.

*Corresponding author: Jacek Sosnowski, PhD, Associate Professor, research interests: plant production, grassland science. Address: Department of Grassland and Green Areas Creation, Siedlce University of Natural Sciences and Humanities, Prusa 14 Street, 08-110 Siedlce, Poland. Tel: +48 25 6431318, Email: jacek.sosmowski@uph.edu.pl. (sms) substrate can be used as such fertilizer. Poland is a leading producer of mushrooms. This country leads in the creation of large amounts of spent mushroom substrate (SMS), an organic waste material which is a problem for the producers. However, it is an extremely valuable organic fertilizermaterial which can be potentially used in agriculture as a good fertilizer ${ }^{[6-9]}$. It is an organic mass that can be converted into humus in the soil. Maszkiewicz ${ }^{[10]}$ states that the content of macronutrients after the mushroom cultivation amounted (g/kg DM): nitrogen 13.0-26.0; phosphorus 1.0-10.0; potassium 5.0-25.0; magnesium 2.0-5.20; calcium 60.0-150.0; sodium $0.5-2.9$. The mushroom substrate is also characterized by high content of microelements and low heavy metals ${ }^{[11-15]}$. SMS is a valuable source of organic matter with a low C:N ratio ${ }^{[7,16-18,]}$. Many researchers also pointed that the high variability and unbalance of the chemical composition of the SMS is an unquestionable drawback, which oblige them to continually control their chemical composition and replenish the missing elements in order to improve the fertilizers propriety ${ }^{[19-22]}$. Another valuable fertilizer is slurry, which is completely different from manure on both physical characteristics and effects on plants. It was pointed out that the nutrients in slurry are present in forms that more easily available to plants than in manure, which makes slurry a fast-acting fertilizer.

The aim of this study was to evaluate fertilizing effects of mushroom substrate and slurry on dry matter productivity and value of legume-grass mixtures.

\section{Material and methods}

The three-year research was conducted in the experimental 
field of the Department of Grasslands and Landscape Architecture Development, the University of Humanities and Natural Sciences in Siedlce from autumn 2012 to 2015. The experiment was replicated three times, with a split-plot arrangement and plots of $3 \mathrm{~m}^{3}$ as experimental units. In the experiment the main research factors were legume-grass mixtures and organic fertilizers with high organic matter content (spent mushroom substrate and cow slurry, used separately and in various combinations).

The experiment consisted of the following units:

1. control (no fertilization) (0);

2. SMS $\left(30 \mathrm{t} / \mathrm{hm}^{2}\right)(\mathrm{PP})$;

3. slurry $\left(60 \mathrm{~m}^{3} / \mathrm{hm}^{2}\right)(\mathrm{G})$;

4. SMS $\left(10 \mathrm{t} / \mathrm{hm}^{2}\right)+$ slurry $\left(60 \mathrm{~m}^{3} / \mathrm{hm}^{2}\right)(\mathrm{PP} 10+\mathrm{G} 60)$;

5. SMS $\left(20 \mathrm{t} / \mathrm{hm}^{2}\right)+$ slurry $\left(40 \mathrm{~m}^{3} / \mathrm{hm}^{2}\right)(\mathrm{PP} 20+\mathrm{G} 40)$;

6. SMS $\left(30 \mathrm{t} / \mathrm{hm}^{2}\right)+$ slurry $\left(20 \mathrm{~m}^{3} / \mathrm{hm}^{2}\right)(\mathrm{PP} 30+\mathrm{G} 20)$.

In the experiment three plant species were involved: Medicago $x$ varia T. Martyn (alfalfa hybrid), the variety of Tula, Dactylis glomerata (cock's foot) of the Bora variety, and Lolium perenne (perennial ryegrass) of durable variety Info. These species were grown as three types of legume-grass mixtures:

M1 - Dactylis glomerata, Lolium perenne, Medicago x varia $\mathrm{T}$. Martyn;

M2 - Dactylis glomerata, Medicago x varia T. Martyn;

M3 - Lolium perenne, Medicago x varia T. Martyn.

In the above mixtures the amount of each component was the same. In the experiment, organic fertilizer was used in the form of slurry and SMS. SMS was applied once at the start of the experiment, before the growing season, in different doses mixed with the soil. Slurry was used every year throughout the experiment, in equal doses after each harvest. Table 1 presents chemical composition of slurry and SMS.

Table 1 Concentration of selected macro-elements $\left(\mathrm{g} \cdot \mathrm{kg}^{-1} \mathrm{DM}\right)$ in mushroom substrate and slurry

\begin{tabular}{ccc}
\hline Nutrient & SMS & Slurry \\
\hline $\mathrm{N}$ & 24.50 & 48.00 \\
$\mathrm{P}$ & 9.50 & 12.64 \\
$\mathrm{~K}$ & 13.20 & 43.16 \\
$\mathrm{Ca}$ & 58.20 & 30.75 \\
\hline
\end{tabular}

Table 2 The value of Sielianinov's hydrothermal coefficient (K) in the growing season

\begin{tabular}{cccccccc}
\hline \multirow{2}{*}{ Year } & \multicolumn{7}{c}{ Month } \\
\cline { 2 - 8 } & April & May & June & July & August & September & October \\
\hline \multirow{2}{*}{2013} & 2.56 & 3.07 & 2.11 & 0.84 & 0.78 & 2.53 & 0.60 \\
& $(\mathrm{sw})$ & $(\mathrm{ew})$ & $(\mathrm{w})$ & $(\mathrm{d})$ & $(\mathrm{d})$ & $(\mathrm{sw})$ & $(\mathrm{sd})$ \\
2014 & 1.36 & 1.87 & 1.64 & 0.59 & 1.92 & 0.64 & 0.12 \\
& $(\mathrm{o})$ & $(\mathrm{mw})$ & $(\mathrm{mw})$ & $(\mathrm{sd})$ & $(\mathrm{mw})$ & $(\mathrm{sd})$ & $(\mathrm{ed})$ \\
2015 & 1.22 & 2.63 & 0.87 & 1.08 & 0.18 & 1.46 & 1.94 \\
& $(\mathrm{md})$ & $(\mathrm{sw})$ & $(\mathrm{d})$ & $(\mathrm{md})$ & $(\mathrm{ed})$ & $(\mathrm{o})$ & $(\mathrm{dw})$ \\
\hline
\end{tabular}

Note: $\mathrm{K} \leq 0.4$ extreme drought (ed). $\quad 0.4<\mathrm{K} \leq 0.7$ severe drought (sd). $\quad 0.7<$ $\mathrm{K} \leq 1.0$ drought $(\mathrm{d}) . \quad 1.0<\mathrm{K} \leq 1.3$ moderate drought $(\mathrm{md}) . \quad 1.3<\mathrm{K} \leq 1.6$ optimal (o). $\quad 1.6<\mathrm{K} \leq 2.0$ moderately wet (mw). $2.0<\mathrm{K} \leq 2.5$ wet (w). $2.5<$ $\mathrm{K} \leq 3.0$ severely wet (sw). $\mathrm{K}>3.0$ extremely wet (ew)

The experiment was set up on the soil of the granulometric composition of loamy sand, of the order of anthropogenic, the type of culture earth soil, and the subtype of hortisole. Chemical analysis of the soil indicated high content of absorbable forms of phosphorus and magnesium. However, absorbable forms of potassium were within the limits of the average content. Sielianinov's hydrothermal coefficient was calculated in order to determine temporal variation of meteorological elements and their effects on vegetation.

Optimal temperature and moisture conditions occurred only in April 2014 and September 2015. In the remaining months of the growing periods, the weather conditions were not favourable, varying from extremely wet in May 2013 to extremely dry in August 2015. Throughout the experiment the best conditions occurred at the beginning of each growing period. It can be concluded that the most difficult situation for plants was in 2015 . Except May 2015 and the end of the growing period, the weather ranged from moderately dry to extremely dry.

During each growing season all the mixtures were harvested three times. The fresh matter from each plot was weighed and a sample of $0.6 \mathrm{~kg}$ was obtained to determine dry matter content and to perform chemical analysis for the amount of total protein and crude fibre. The chemical composition of the plants was determined with near-infrared spectroscopy (NIRS) using the NIRFlex N-500 spectrometer. The results of the research were processed statistically using a three-factor analysis of variance. The Fisher-Snedecor test was done to determine the significance of the effects of experimental factors on the parameters tested in the study. Tukey's test was used to compare means at the $\mathrm{LSD}_{0.05}$ significance level. All the calculations were made with the Statistica 6.0-2001 program.

\section{Results and discussion}

According to Burns et al. ${ }^{[23]}$, minimum protein concentration of feed for dairy cows should be ranging from $150 \mathrm{~g} / \mathrm{kg}$ to $170 \mathrm{~g} / \mathrm{kg}$. The increase of protein content in the feed increases its digestibility, regardless of its quality. Protein content of the forage tested in the experiment was dependent on both the type of fertilizer applied and the type of legume-grass mixture (Table 3 and 4).

Irrespective of the type of mixture (Table 3), the highest concentration of total protein was in the forage from the plot where $20 \mathrm{t} / \mathrm{hm}^{2}$ of mushroom substrate was applied together with $40 \mathrm{~m}^{3} / \mathrm{hm}^{2}$ of slurry $\left(206.36 \mathrm{~g} / \mathrm{hm}^{2}\right)$, as well as from the object fertilized with slurry on its own $\left(205.76 \mathrm{~g} / \mathrm{hm}^{2}\right)$. On the other plots protein concentration in the forage was significantly lower, with the lowest obtained from the control unit $\left(180.66 \mathrm{~g} / \mathrm{hm}^{2}\right)$. An increase in protein content in crops after SMS application was also confirmed by Wiśniewska-Kadżajan and Jankowski ${ }^{[9]}$. Other studies also show the beneficial effect of the use of natural fertilizer on legume-grass mixtures ${ }^{[4]}$.

Protein content in the forage varied throughout the research (Table 3). The highest protein concentration was obtained in the fodder harvested in the second year, i.e. $2014(207.55 \mathrm{~g} / \mathrm{kg})$ and the lowest protein concentration was obtained in the third year, i.e. $2015(180.75 \mathrm{~g} / \mathrm{kg})$. Differences in protein content in the mixtures harvested in different years of research were not statistically significant. According to Wiśniewska-Kadżajan and Jankowski ${ }^{[9]}$, reduction of protein content in the third year of their study stemmed from a short period of mushroom substrate effect as a nutrient. This is due to the narrow $\mathrm{C}: \mathrm{N}$ ratio and the nitrogen mineralization process ${ }^{[24]}$. The present findings point to relationship between the effects of the type of fertilizer and the type of legume-grass mixture. The value of parameters examined in the fodder also varied depending on the type of legume-grass mixture and the harvest (Table 4). Among all legume-grass mixtures, the highest content of protein was in the M3 mixture of Lolium perenne and Medicago $x$ varia T. Martyn $(198.54 \mathrm{~g} / \mathrm{kg})$, and lowest was in the M1 mixture with Dactylis 
glomerata, Lolium perenne, and Medicago x varia T. Martyn $(194.06 \mathrm{~g} / \mathrm{kg})$.

There was also diversity in protein content of the fodder from individual harvests. Regardless of the type of legume-grass mixture, the highest total protein concentration was obtained in the second harvest (199.54 g/kg), and slightly lower (negligible statistically) in the third harvest $(198.60 \mathrm{~g} / \mathrm{kg})$. In the first harvest total protein concentration was significantly lower $(190.64 \mathrm{~g} / \mathrm{kg})$ than previous harvests. The effect of the harvest on the protein content in the dry matter is confirmed in literature ${ }^{[7,25,26]}$. Thus, there was a correlation between the type of legume-grass mixture and both the harvest and the type of fertilizer.

Table 3 Effects of fertilizer on total protein concentration in the dry matter $\left(\mathrm{g}^{\mathrm{kg}} \mathrm{kg}^{-1}\right)$

\begin{tabular}{|c|c|c|c|c|c|c|c|c|}
\hline \multirow{2}{*}{ Mixture (C) } & \multirow{2}{*}{ Year (B) } & \multicolumn{6}{|c|}{ Fertilizer applied (A) } & \multirow{2}{*}{ Mean } \\
\hline & & 0 & PP & G & $\mathrm{P} 10+\mathrm{G} 60$ & $\mathrm{P} 20+\mathrm{G} 40$ & $\mathrm{P} 30+\mathrm{G} 20$ & \\
\hline \multirow{3}{*}{ M1 } & 2013 & 175.78 & 190.43 & 185.82 & 212.2 & 214.46 & 175.47 & 192.36 \\
\hline & 2014 & 189 & 214.62 & 214.9 & 212.43 & 231.16 & 206.58 & 211.45 \\
\hline & 2015 & 178.82 & 176.43 & 185.31 & 173.14 & 188.41 & 168.12 & 178.37 \\
\hline \multirow{3}{*}{ M2 } & 2013 & 187.11 & 241.02 & 239.47 & 167.79 & 205.84 & 173.54 & 202.46 \\
\hline & 2014 & 190.44 & 224.17 & 209.4 & 188.51 & 211.4 & 204.71 & 204.77 \\
\hline & 2015 & 179.91 & 185.39 & 194.24 & 185.22 & 171.99 & 171.01 & 181.29 \\
\hline \multirow{3}{*}{ M3 } & 2013 & 167.67 & 178.79 & 228.43 & 238.33 & 225.6 & 200.82 & 206.61 \\
\hline & 2014 & 176.44 & 194.46 & 213.58 & 210.09 & 225.68 & 218.4 & 206.44 \\
\hline & 2015 & 180.76 & 191.46 & 180.69 & 202.52 & 182.69 & 157.37 & 182.58 \\
\hline \multicolumn{2}{|c|}{ Mean values of fertilizer effect } & 180.66 & 199.64 & 205.76 & 198.92 & 206.36 & 186.22 & 196.26 \\
\hline \multicolumn{9}{|c|}{ Mean values in subsequent years } \\
\hline \multicolumn{2}{|c|}{2013} & 176.85 & 203.41 & 217.91 & 206.11 & 215.3 & 183.28 & 200.48 \\
\hline \multicolumn{2}{|c|}{2014} & 185.3 & 211.08 & 212.63 & 203.68 & 222.74 & 209.9 & 207.55 \\
\hline \multicolumn{2}{|c|}{2015} & 179.83 & 184.43 & 186.75 & 186.96 & 181.03 & 165.5 & 180.75 \\
\hline
\end{tabular}

$\mathrm{LSD}_{0.05}$ for: $\mathrm{A}=4.03 ; \mathrm{B}=2.33 ; \mathrm{C}=2.33 ; \mathrm{B} / \mathrm{C}=4.04 ; \mathrm{C} / \mathrm{B}=4.04 ; \mathrm{C} / \mathrm{A}=4.04 ; \mathrm{A} / \mathrm{B}=6.97 ; \mathrm{A} / \mathrm{C}=4.93 ; \mathrm{B} / \mathrm{A}=5.71$

Note: M1 - Dactylis glomerata, Lolium perenne, Medicago x varia T. Martyn; M2 - Dactylis glomerata, Medicago x varia T. Martyn; M3 - Lolium perenne, Medicago $x$ varia $\mathrm{T}$. Martyn.

Table 4 Effects of fertilizer on total protein concentration in the dry matter $\left(\mathrm{g}^{\mathrm{kg}} \mathrm{kg}^{-1}\right)$

\begin{tabular}{|c|c|c|c|c|c|c|c|c|}
\hline \multirow{2}{*}{ Mixture (C) } & \multirow{2}{*}{ Harvest (B) } & \multicolumn{6}{|c|}{ Fertilizer combination (A) } & \multirow{2}{*}{ Mean } \\
\hline & & 0 & PP & G & $\mathrm{P} 10+\mathrm{G} 60$ & $\mathrm{P} 20+\mathrm{G} 40$ & $\mathrm{P} 30+\mathrm{G} 20$ & \\
\hline \multirow{3}{*}{ M1 } & I & 177.89 & 195.72 & 199.48 & 193.70 & 214.83 & 167.02 & 191.44 \\
\hline & II & 183.88 & 186.68 & $195.7 ; 5$ & 212.85 & 213.27 & 186.31 & 196.46 \\
\hline & III & 181.84 & 199.09 & 190.80 & 191.23 & 205.92 & 196.84 & 194.28 \\
\hline \multirow{2}{*}{ M2 } & I & 186.89 & 209.28 & 195.12 & 160.99 & 191.56 & 157.44 & 183.55 \\
\hline & III & 190.80 & 233.45 & 235.50 & 192.43 & 203.28 & 212.40 & 211.31 \\
\hline \multirow{3}{*}{ M3 } & I & 170.00 & 176.96 & 211.33 & 235.20 & 207.98 & 180.12 & 196.93 \\
\hline & II & 191.95 & 220.02 & 203.86 & 201.89 & 228.98 & 204.21 & 208.49 \\
\hline & III & 162.92 & 167.73 & 207.51 & 213.85 & 197.01 & 192.25 & 190.21 \\
\hline \multicolumn{9}{|c|}{ Mean values of species effect } \\
\hline & M2 & 185.82 & 216.86 & $214.3 ; 7$ & 180.51 & 196.41 & 183.09 & 196.18 \\
\hline & M3 & 174.96 & 188.24 & 207.57 & 216.98 & 211.32 & 192.20 & 198.54 \\
\hline \multicolumn{9}{|c|}{ Mean values of harvest effect } \\
\hline & I & 178.26 & 193.99 & 201.98 & 196.63 & 204.79 & 168.19 & 190.64 \\
\hline & II & 185.20 & 204.85 & 204.03 & 200.95 & 212.22 & 189.98 & 199.54 \\
\hline & III & 178.52 & 200.09 & 211.27 & 199.17 & 202.07 & 200.50 & 198.60 \\
\hline
\end{tabular}

$\mathrm{LSD}_{0.05}$ for: $\mathrm{A}=3.29 ; \mathrm{B}=1.91 ; \mathrm{C}=1.91 ; \mathrm{B} / \mathrm{C}=3.30 ; \mathrm{C} / \mathrm{B}=3.30 ; \mathrm{C} / \mathrm{A}=3.30 ; \mathrm{A} / \mathrm{B}=5.70 ; \mathrm{A} / \mathrm{C}=4.03 ; \mathrm{B} / \mathrm{A}=4.67$

Note: M1 - Dactylis glomerata, Lolium perenne, Medicago x varia T. Martyn; M2 - Dactylis glomerata, Medicago x varia $\mathrm{T}$. Martyn; M3 - Lolium perenne, Medicago $x$ varia $\mathrm{T}$. Martyn.

The optimal concentration of crude fibre in feed for ruminants should be $200-250 \mathrm{~g} / \mathrm{kg} \mathrm{DM}$, and it should not exceed $280 \mathrm{~g} / \mathrm{kg}$ $\mathrm{DM}^{[23]}$. When the amount of fibre is too high, it causes a feeling of satiety in animals while demand for nutrients has not been met because of the low content of energy-yielding nutrients.
According to Staniak and Księżak ${ }^{[27]}$ raw fibre is essential for proper metabolism in the gastrointestinal tract of cattle. In a well-balanced feed ration the minimum amount of crude fibre for cattle should be $13 \%$, and for dairy cows $18 \%-22 \%$.

Crude fibre content in the mixtures varied from year to year 
and was differentiated depending on the type of fertilizer applied and the harvest (Table 5 and 6). Regardless of the type of mixture, the largest fibre concentration was in the forage from the control (268.92 g/kg DM) and from the plot with the highest dose of SMS and the lowest dose of slurry $(264.80 \mathrm{~g} / \mathrm{kg} \mathrm{DM})$. The lowest concentration of fibre was in the fodder form the plots were fertilizers were used: PP20 + G40 $(252.09 \mathrm{~g} / \mathrm{kg} \mathrm{DM})$ and PP10 + G60 (252.47 g/kg DM). These differences were statistically significant. The results are confirmed by other authors $^{[28]}$, who show that organic fertilizer reduces fibre content in fodder.

Fibre content varied from year to year (Table 5). Forage collected in the last year of the experiment (2015) had the highest fibre concentration $(267.49 \mathrm{~g} / \mathrm{kg} \mathrm{DM})$. A steady increase of fibre content in legume-grass mixtures in successive years of the experiment was also shown by Sosnowski ${ }^{[29,30]}$. However, quite different results were obtained by Wilczek and Ćwintal ${ }^{[31]}$, with the content of fibre in alfalfa grown on its own being reduced in subsequent years. Alfalfa is a plant with a high concentration of fibre $(230-300 \mathrm{~g} / \mathrm{kg} \mathrm{DM})$ in comparison with other legume plants ${ }^{[1]}$. In the present experiment a significant increase in this content could be due to the fact that grass was replaced by alfalfa because of prolonged droughts and high temperatures in the growing periods (Table 2).

Table 5 Effects of fertilizers on fibre concentration in the dry matter $\left(\mathrm{g}^{\mathrm{kg}} \mathrm{gg}^{-1}\right)$

\begin{tabular}{|c|c|c|c|c|c|c|c|c|}
\hline \multirow{2}{*}{ Mixture (C) } & \multirow{2}{*}{ Year (B) } & \multicolumn{6}{|c|}{ Fertilizer combination (A) } & \multirow{2}{*}{ Mean } \\
\hline & & 0 & PP & G & $\mathrm{P} 10+\mathrm{G} 60$ & $\mathrm{P} 20+\mathrm{G} 40$ & $\mathrm{P} 30+\mathrm{G} 20$ & \\
\hline \multirow{3}{*}{ M1 } & 2013 & 277.22 & 267.36 & 258.71 & 232.02 & 263.71 & 277.99 & 262.84 \\
\hline & 2014 & 275.22 & 260.46 & 260.17 & 252.62 & 238.63 & 270.07 & 259.53 \\
\hline & 2015 & 233.81 & 283.11 & 265.93 & 276.16 & 271.59 & 280.7 & 268.55 \\
\hline \multirow{3}{*}{ M2 } & 2013 & 256.33 & 239.4 & 223.41 & 233.23 & 238.06 & 267.99 & 243.07 \\
\hline & 2014 & 259.33 & 236.72 & 258.92 & 269.69 & 266.86 & 254.28 & 257.63 \\
\hline & 2015 & 274.22 & 262.71 & 254.19 & 258.48 & 264.11 & 272.08 & 264.3 \\
\hline \multirow{3}{*}{ M3 } & 2013 & 294.22 & 306.37 & 238.31 & 233.73 & 221.22 & 247.48 & 256.89 \\
\hline & 2014 & 273.33 & 257.96 & 256.21 & 258.79 & 246.1 & 242.21 & 255.77 \\
\hline & 2015 & 276.6 & 278.89 & 279.35 & 257.5 & 258.55 & 304.36 & 269.61 \\
\hline \multicolumn{2}{|c|}{ Mean values of fertilizer effect } & 268.92 & 265.89 & 255.02 & 252.47 & 252.09 & 264.4 & 259.8 \\
\hline \multicolumn{9}{|c|}{ Mean values for subsequent years } \\
\hline \multicolumn{2}{|c|}{2013} & 275.93 & 271.04 & 240.14 & 233 & 241 & 264.49 & 254.26 \\
\hline \multicolumn{2}{|c|}{2014} & 269.3 & 251.71 & 258.43 & 260.37 & 250.53 & 255.52 & 257.64 \\
\hline \multicolumn{2}{|c|}{2015} & 261.54 & 274.9 & 266.49 & 264.05 & 264.75 & 273.19 & 267.49 \\
\hline
\end{tabular}

$\mathrm{LSD}_{0.05}$ for: $\mathrm{A}=3.54 ; \mathrm{B}=2.05 ; \mathrm{C}=2.05 ; \mathrm{A} / \mathrm{C}=4.34 ; \mathrm{C} / \mathrm{A}=3.55 ; \mathrm{B} / \mathrm{C}=3.55 ; \mathrm{C} / \mathrm{B}=3.55 ; \mathrm{A} / \mathrm{B}=6.13 ; \mathrm{B} / \mathrm{A}=5.03$

Note: M1 - Dactylis glomerata, Lolium perenne, Medicago x varia T. Martyn; M2 - Dactylis glomerata, Medicago x varia T. Martyn; M3 - Lolium perenne, Medicago $x$ varia $\mathrm{T}$. Martyn.

The high proportion of alfalfa in the yield of the mixtures, especially in years with a deficiency of rain, was noticed by other authors ${ }^{[23]}$. In addition, Jankowski and Jodełka ${ }^{[6]}$ proved in their studies that water stress increases fibre content in white clover. However, it was studied by Sosnowski ${ }^{[29,30]}$ that the response of plants to water shortage depends on the species, and the same author concluded that water stress results in reduced amount of fibre in some grass species. Additionally, Jankowski and Jodełka $^{[6]}$ noted an increase in fibre content caused by high temperature.

By analyzing fertilizer effects throughout the research (Table 5), it was shown that in 2015 , as opposed to previous years, the application of SMS and slurry did not result in a reduction of fibre content, while the use of slurry significantly increased its content compared to previous years. This phenomenon may be due to the fact that on the plot without fertilizer the plants grew slowly due to drought in 2015 (Table 2). Application of organic fertilizer resulted in better development of legume-grass mixtures, plants were stronger, taller, and contained more fibre.

Analysing the legume-grass mixtures further (Table 6) discovered that regardless of the fertilization the M1 mixture with Dactylis glomerata, Lolium perenne, and Medicago $x$ varia $\mathrm{T}$. Martyn accumulated the highest amount of crude fibre, while the M2 mixture with Dactylis glomerata and Medicago $x$ varia $\mathrm{T}$. Martyn contained the least fibre $(255.00 \mathrm{~g} / \mathrm{kg})$. The differences between the mixtures were statistically significant. Gawe ${ }^{[3]}$ also confirmed different fibre content in different alfalfa-grass mixtures.

Taking into account different mixtures and different fertilizer combinations, it was found that both the first and the second mixture accumulated the highest amount of crude fibre after applying $30 \mathrm{t}$ of spent mushroom substrate and $20 \mathrm{~m}^{3}$ of slurry, while the mixture of Lolium perenne and Medicago $x$ varia $\mathrm{T}$. Martyn accumulated the most fibre on the control plot $(281.38 \mathrm{~g} / \mathrm{kg})$ and on the plot with mushroom substrate $(281.07 \mathrm{~g} / \mathrm{kg})$. In the case of all three mixtures the use of slurry resulted in a decrease in fibre content.

By analyzing fibre content in forage from individual harvests (Table 6), regardless of the type of fertilizer applied, it was shown that its content decreased in successive harvests. However, taking into account both the type of mixture and the harvest, this relationship was different. Only in the mixture of Dactylis glomerata and Medicago $x$ varia T. Martyn, did fibre content significantly decrease in subsequent harvests. The mixture of Dactylis glomerata, Lolium perenne, and Medicago $x$ varia $\mathrm{T}$. Martyn contained the most fibre in the second harvest $(270.20 \mathrm{~g} / \mathrm{kg})$. In the mixture of Lolium perenne with Medicago $x$ varia T. Martyn, there was the least fibre in the second harvest $(257.59 \mathrm{~g} / \mathrm{kg})$, and the most in the third $(265.62 \mathrm{~g} / \mathrm{kg})$. The decrease in fibre content in subsequent harvests of legume-grass mixtures was also recorded by other authors ${ }^{[4,28,31,32]}$ 
Table 6 Effects of fertilizer and harvest on fibre concentration in the dry matter $\left(\mathrm{g} \mathrm{kg}^{-1}\right)$

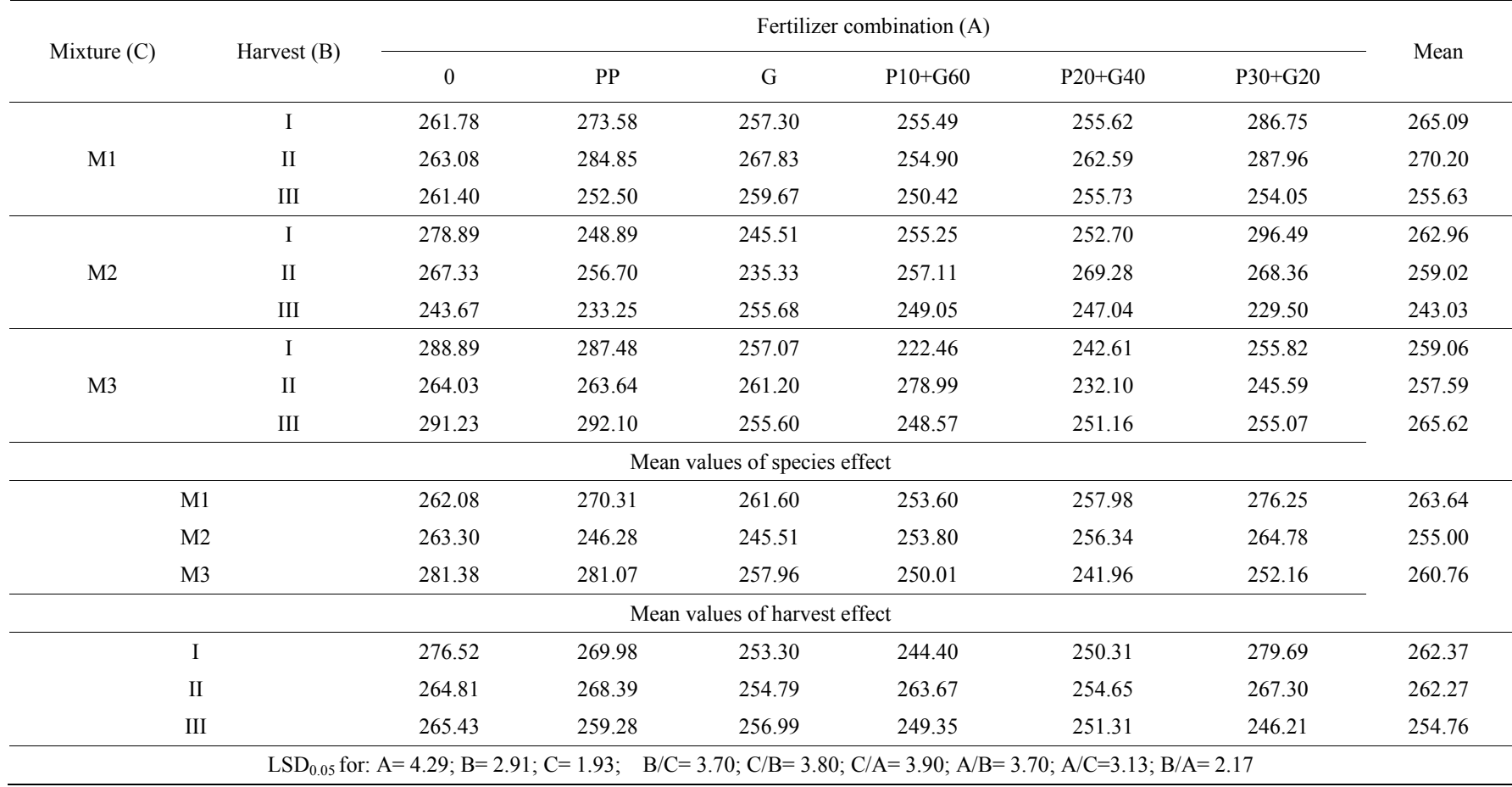

Note: M1 - Dactylis glomerata, Lolium perenne, Medicago x varia T. Martyn; M2 - Dactylis glomerata, Medicago x varia $\mathrm{T}$. Martyn; M3 - Lolium perenne, Medicago $x$ varia $\mathrm{T}$. Martyn.

\section{Conclusions}

In the experiment the contents of total protein and crude fibre were dependent on the type of fertilizer and the type of mixture. Regardless of the type of mixture, forage from the plots with $20 \mathrm{t} / \mathrm{hm}^{2}$ of mushroom substrate and $40 \mathrm{~m}^{3} / \mathrm{hm}^{2}$ of slurry had the best nutritional value, with the highest amount of total protein. The contents of protein and crude fibre in the forage were more favourably affected by slurry than by spent mushroom substrate. Out of the mixtures from all plots, regardless of the type of fertilizer, the mixture consisting of Lolium perenne and Medicago $x$ varia $\mathrm{T}$. Martyn contained the highest content of protein. Fodder from this mixture from the plot with $10 \mathrm{t} / \mathrm{hm}^{2}$ spent mushroom substrate with $60 \mathrm{~m}^{3}$ of slurry contained the highest amount of protein.

\section{Acknowledgements}

The research carried out under the theme No 357/13/S was financially supported by the science grant of the Ministry of Science and Higher Education.

\section{[References]}

[1] Gaweł E. Specific and mineral composition of organically grown legume-grass mixtures under combined hay and grazing regime. Pol. J. Agron., 2011; 6: 17-26.

[2] Krzywiecki S, Szyszkowska A, Preś J. Nutritional value of red clover with meadow fescue mixtures depending on the contribution of components and conservation method. Rocz. Nauk. Zoot. Rozpr., 1991; 30: 83-96. (in Polish)

[3] Gawel E. The effect of the way and frequency of utilization of lucerne-grass mixtures on their yield, botanical composition and quality. Water-Environment-Rural Areas, 2008; 24: 5-18. (in Polish)

[4] Bittman S, Waddington J, McCartney D H. Performance of alfalfa strains grown in mixture with smooth bromegrass as affected by management. Can. J. Plant Sci., 1991; 71: 1029-1037.

[5] Foster A, Vera C L, Malhi S S, Clarke F R. Forage yield of simple and complex grasslegume mixtures under two management strategies Can. J.
Plant Sci., 2014; 94: 41-50.

[6] Jankowski K., Jodełka J. Analysis of influence of climatic on feding and nutritive value of fourth Grass-legume mixtures. Zesz. Nauk. AP w Siedlcach. Rolnictwo, 2000; 57: 93-101. (in Polish)

[7] Eiland F, Leth M, Klamer M, Lind A M, Jensen, H.E.K., Iversen J J L. 2001. $\mathrm{C}$ and $\mathrm{N}$ turnover and lignocellulose degradation during composting of Miscanthus straw and liquid pig manure. Compost Science \& Utilization, 2001; 9(3): 186-196

[8] Kryszak J. Economic value of legume-grass mixtures in field cultivation. Rocz. AR Poznań. Rozpr. Nauk., 2003; 338: 108. (in Polish)

[9] Wiśniewska-Kadżajan B, Jankowski K. Effect of mushroom substrate supplemented with minerals on yield of biomass and protein of orchard grass. Acta Agroph, 2015; 22(3): 335-344. (in Polish)

[10] Maszkiewicz J. Used mushroom substrate as fertilizer and fuel. In: Mushrooms. Mushroom Producer Bulletin. Wyd. Hortpress, 2010; 1: 59-60. (in Polish)

[11] Maher M J, Smyth S, Dodd V A, McCabe T, Magette W L, Duggan J, et al Managing spent mushroom compost. Teagasc, Dublin, 2000; pp.111-121.

[12] Uzun I. Use of spent mushroom compost in sustainable fruit production. J. Fruit Ornam. Plant Res., 2004; 12: 157-165.

[13] Niżewski P, Dach J, Jędruś A. Management of mushrooms subgrade waste by composting process. J. Res. And Apel. Agricul. Engineer., 2006; 51(1): 24-27. (in Polish)

[14] Jordan S N, Mullen G J, Murphy M C. Composition variability of spent mushroom composts in Ireland. Bioresource Technology, 2008; 99: $411-418$.

[15] Rutkowska B, Szulc W, Stępień W, Jobda J. Possibility of agricultural utilization of spent mushroom substrates. Advances of Agricultural Sciences Problem Issues, 2009; 535: 349-354. (in Polish)

[16] Wiśniewska-Kadżajan B. Assessment of usefulness of the substrate after mushrooms growing to plant fertilization. Environmental Protection and Natural Resources, 2012; 54: 165-176. (in Polish)

[17] Wiśniewska-Kadżajan B., Fertilization effect of mineral NPK, organic farmyard manure and mushroom's compost on the content and uptaking of potassium and magnesium by the meadow sward. Folia Pomer. Univ. Technol. Stetin. Agric. Aliment. Pisc. Zootech., 2013; 304(26): 107-116. (In Polish)

[18] Kalembasa D, Majchrowska-Safaryan A. Affluence of the spent mushroom substrate from mushroom growing cellar. Advances of Agricultural Sciences Problem Issues, 2009; 535: 195-200. (in Polish)

[19] Rao J R, Watabe M, Stewart T A, Millar B C, Moore J E. Pelleted organomineral fertilizers from composted pig slurry solids, animal wastes 
and spent mushroom compost for amenity grasslands. Waste Management, 2007; 27: 1117-1128.

[20] Polat E, Uzun I H, Topcuoglu B, Önal K., Onus A N, Karaca M. Effects of spent mushroom compost on quality and productivity of cucumber (Cucumis dativus L.) grown in greenhouses. African J. of Biotechnology, 2009; 8(2): 176-180.

[21] Salomez J, De Bolle S, Sleutel S, De Neve S, Hofman G, Nutrient Legislation in Flanders (Belgium). Proceedings, More sustainability in agriculture: New fertilizers and fertilization management. Rome, 2009; pp.546-551.

[22] Szudyga K. Mushroom. In: Mushrooms. Mushroom Producer Bulletin. Wyd. Hortpress, 2011; 1, 8-13. (In Polish)

[23] Burns G A, Gilliland T J, Grogan D, O'Kiely P. Comparison of the agronomic effects of maturity and ploidy in perennial ryegrass. Grassland a European Resource? Red. Goliński P, Warda M, Stypiński P. EGF. Grassland Sciences and Europe, 2012; 17: 349-351.

[24] Becher M. Chemical composition of spent mushroom substrate after cultivation of agaricus bisporus as a waste organic material. Economics and Environment, 2013; 4(47): 207-213.

[25] Fagerberg, 1996; Fagerberg B. The quantitative effect of weather on growth and nutritional value of grass leys. 16th EGF Meeting on Grassland and Land Use Systems, 1996; pp.83-86.

[26] Tonn B, Bienvenu C, Isselstein J. Assessing quantity and quality of grazed forage on multi-species swards. The role of grasslands in a green future. Red. Á. Helgadóttir. A. Hopkins. EGF. Grassland Sciences in Europe, 2013; 18: 82-84.

[27] Staniak M, Księżak J. Chemical composition of Festulolium braunii-Trifolium pratense mixtures in relation to nitrogen fertilisation and the share of components. Water-Environment-Rural Areas 2008; 2b(24): 163-173. (In Polish)

[28] Wróbel B, Zielińska K J, Fabiszewska A U. The effect of mineral NPK and organic fertilisation on the content of nutritive components and microbiological quality of the first regrowth of meadow sward. J. Res. Appl. Agr. Eng., 2012; 60(4): 129-134.

[29] Sosnowski J. The feed value of Festulolium braunii mixtures with red clover and alfalfa supplied with soil's fertilizer. Grassland Science in Poland 2011; 14: 127-135. (in Polish)

[30] Sosnowski J. The effect of different factors on the quality of feed components. Ecol Chem Eng A., 2012; 9(11): 1331-1339.

[31] Wilczek M, Ćwintal M. Influence of fertilization on the content of basic organic and mineral components in alpha hybrid alfalfa harvested 3 and 4 times. Vol. I. Organic ingredients. Biul. IHAR, 1996; 197: 187-194. (in Polish)

[32] Crème A, Rumpel C, Gastal F, Gil M L M, Chabbi A. Effects of grasses and a legume grown in monoculture or mixture on soil organic matter and phosphorus forms. Plant and Soil, 2015; 402, 117-128. 